\title{
Melanocytes: interface of cell biology and pathobiology with a focus on nitric oxide and cGMP signaling Krassimira Ivanova*1, Pranab Kumar Das ${ }^{2}$ and Rupert Gerzer ${ }^{1}$
}

\author{
Address: ${ }^{1}$ Institute of Aerospace Medicine, German Aerospace Center, Cologne, Germany and ${ }^{2}$ Department of Pathology, Academic Medical \\ Center, University of Amsterdam, The Netherlands \\ Email: Krassimira Ivanova* - krassimira.ivanova@dlr.de \\ * Corresponding author
}

from $3^{\text {rd }}$ International Conference on cGMP Generators, Effectors and Therapeutic Implications

Dresden, Germany. I5-17 June 2007

Published: 25 July 2007

BMC Pharmacology 2007, 7(Suppl I):S3 I doi:I0.II86/I47|-22I0-7-SI-S3 I

This abstract is available from: http://www.biomedcentral.com/I47I-22I0/7/SI/S3 I

(c) 2007 Ivanova et al; licensee BioMed Central Ltd.

Human epidermal melanocytes represent a crucial protective barrier against UV irradiation and oxidative stress by generating the radical scavenging pigment melanin. Melanin is also known to act as a photosensitizer that generates active oxygen species upon UV irradiation, which may initiate hypopigmentary disorders (e.g., vitiligo) as well as UV-induced oncogene cell transformation. Finally, melanocytes in vivo are permanently targeted by environmental mechanical stimuli.

For human melanocytes, it has been shown that the nitric oxide (NO)-soluble guanylyl cyclase (sGC) pathway, through the activation of cGMP-dependent protein kinase, is involved in UVB-induced melanogenesis [1]. In previous studies we found that different guanylyl cyclase (GC) isoforms are responsible for cGMP synthesis in melanocytic cells. Normal human melanocytes and nonmetastatic melanoma cell lines predominantly express sGC, which appears to be associated with melanogenesis, whereas absence of NO-sensitive GC, but upregulated activities of the membrane isoforms GC-A and GC-B were found in highly metastatic phenotypes [2]. We also showed that NO can induce perturbation of melanocyteextracellular matrix interactions, which may contribute to loss of melanocytes or melanoma metastasis $[3,4]$. The NO effects appear to be modulated partly by cGMP [4].

In the frame of the current space exploration, we further have investigated the regulation of cGMP levels in melanocytes at altered gravity conditions. Our studies indicate that cultured melanocytes and non-metastatic melanoma cells respond to long-time exposure to hypergravity (up to $5 \times \mathrm{g}$ for $24 \mathrm{~h}$ ) with an elevated cGMP efflux under conditions where phosphodiesterase (PDE)-mediated cGMP hydrolysis is inhibited or cGMP synthesis is induced, e.g., by NO [5]. Cyclic GMP efflux was inhibited in the presence of $1 \mu \mathrm{M}$ trequinsin, a highly selective inhibitor of PDE5 and of transport by "multidrug resistance" proteins 4 and 5 (MRP4/5). Transport was further inhibited by probenecid, an inhibitor of endogenous non-selective transporters as well as of MRP4/5 and by cycloheximide as an inhibitor of de novo protein synthesis. It, therefore, can be suggested that the expression of endogenous non-selective cGMP transporters and/or MRP4/5 is increased under elevated acceleration in human melanocytes and non-metastatic melanoma cells. Similar results were found on mRNA levels. In contrast, elevated acceleration does not affect cGMP efflux in highly metastatic melanoma cells. We propose that altered gravity should be regarded as a possible factor that may induce signaling events in human melanocytes via cGMP that could be important for malignant transformation.

\section{References}

I. Romero-Graillet C, Aberdam E, Biagioli N, Massabni W, Ortonne JP, Ballotti R: Ultraviolet $B$ radiation acts through the nitric oxide and cGMP signal transduction pathway to stimulate melanogenesis in human melanocytes. I Biol Chem 1996, 27I:28052-28056.

2. Ivanova K, Das PK, van den Wijngaard RM, Lenz W, Klockenbring T, Malcharzyk V, Drummer C, Gerzer R: Differential expression of functional guanylyl cyclases in melanocytes: Absence of 
nitric oxide-sensitive isoform in metastatic cells. J Invest Dermatol 200 I, I I 6:409-4I6.

3. Ivanova K, Le Poole IC, Gerzer R, Westerhof W, Das PK: Effects of nitric oxide on the adhesion of melanocytes to extracellular matrix components. J Pathol I997, I83:469-476.

4. Ivanova K, van den Wijngaard RM, Gerzer R, Lamers WH, Das PK: Non-lesional vitiliginous melanocytes are not characterized by an increased proneness to nitric oxide-induced apoptosis. Exp Dermatol 2005, 14:445-453.

5. Ivanova K, Zadeh NH, Block I, Das PK, Gerzer R: Stimulation of cyclic GMP efflux in human melanocytes by hypergravity generated by centrifugal acceleration. Pigment Cell Res 2004, i 7:47I-479.

Publish with Bio Med Central and every scientist can read your work free of charge

"BioMed Central will be the most significant development for disseminating the results of biomedical research in our lifetime. "

Sir Paul Nurse, Cancer Research UK

Your research papers will be:

- available free of charge to the entire biomedical community

- peer reviewed and published immediately upon acceptance

- cited in PubMed and archived on PubMed Central

- yours - you keep the copyright

Submit your manuscript here:

http://www.biomedcentral.com/info/publishing_adv.asp 